\title{
Evaluation of water soil erosion processes in forest areas in the Western Sudetes using terrestrial laser scanning and GIS tools
}

\author{
Paweł B. Dąbek ${ }^{1, *}$, Romuald Żmuda ${ }^{1}$, Jakub Szczepański ${ }^{2}$, and Bartlomiej Ćmielewski ${ }^{3}$ \\ ${ }^{1}$ Wrocław University of Environmental and Life Sciences, Institute of Environmental Protection and \\ Development, pl. Grunwaldzki 24, 50-363 Wrocław, Poland \\ ${ }^{2}$ Wrocław University of Environmental and Life Sciences, Department of Landscape Management, \\ ul. Grunwaldzka 53, 50-357 Wrocław, Poland \\ ${ }^{3}$ Wrocław University of Science and Technology, 3D Scanning and Modeling Laboratory - \\ LabScan 3D, ul. Bolesława Prusa 53/55, 50-317 Wrocław, Poland
}

\begin{abstract}
In the terms of forest soil protection function and the limitations of these functions resulting from forest works, the authors aim was to determine the intensity and spatial range of erosion, and the volume of soil material loss resulting by erosion processes and human activities. The remote sensing technique - terrestrial laser scanning (TLS) was used in the research of erosion processes occurring in the mountain forest on the surface of the skid trails. The measurements were performed with laser scanning resolution of $3 \times 4 \mathrm{~mm}$. Obtained points clouds have been interpolated to the digital terrain models $1 \mathrm{~cm}$, which allowed evaluating the erosion phenomena using the method of differential models in the period of 2011-2013. In the study it was analysed the part of the skid trail (ca. $41 \mathrm{~m}^{2}$, ca. $35 \%$ average slope). It was determined that during the entire research period the amount of soil material loss was ca. $1.9 \mathrm{~m}^{3}$. The erosion processes occurred mainly in the form of sheet erosion with volume ca. $1.3 \mathrm{~m}^{3}$. The erosion processes in the form of sheet erosion occurred ca. $49 \%$ and $42 \%$ of trail section area, respectively. Results of the study indicate that it is efficient to use TLS for the monitoring of the erosion phenomena, qualitative and spatial range assessment. At the same time, it has been proven that intensive water erosion processes can also occur in forests.
\end{abstract}

\section{Introduction}

In Poland, soil erosion is one of the leading factors degrading the natural environment, both in terms of the range and effects of phenomena, as well as the intensity of impact. Forest areas in Poland constitute ca. 30\% of the country's area. In the 1990s, it was determined that approximately $1.4 \%$ of forest areas in Poland are threatened by water erosion [1]. In a dozen years later, it has already been determined that ca. $8 \%$ of the forest area in Poland is threatened by erosion processes [2]. In the Sudetes, medium and strong erosion

\footnotetext{
* Corresponding author: pawel.dabek@upwr.edu.pl
} 
occurs at ca. $45 \%$ of the region's area. This is due to from significant relative heights, large slopes and high annual rainfall [2]. The area of the Sudetes was also classified as a region with degradation on an average level of actual soil erosion [3].

Erosion processes on forested slopes in the Sudetes are mainly initiated by anthropogenic activity. Interference in the natural balance of ecosystems is taking place by changing landuse land cover and the transformation of the relief, as well as changing soil endurance parameters [4]. With forest proper condition, water erosion in forest areas should practically not take place, or only show local character [5-6]. The conducted skidding, as well as the cultivate work and effects of these operations, as well as the localisation and using the forest roads and trails network negatively affect the retention capacity and the effectiveness of soil protection functions of forest complex [7-8]. This leads not only to an increase in outflow from forest catchments, but also to intensification of soil erosion, which is the result of a surface flushing and concentration of runoff on the surface of forest roads and skid trails [9].

One of the main factors intensifying water erosion is the incorrect location of forest skid trails and roads in the land relief [10], which is specifically defined for Polish forests in special design guidelines [11]. Even over $90 \%$ of soil erosion material from forest areas could come from road surfaces [7]. In highly relief areas, water erosion occurs on embankments of slope roads could generate about $70-90 \%$ of soil material loss from the entire roads network of the area [12]. In studies on the intensity of erosion on the surface of skid trails, it was shown that the amount of soil material loss by erosion from the skid trails is ca. 30times greater than in the adjacent forest area [13]. Such intensity of erosion processes is particularly noticeable in the period of 1-2 years from the date of the logging.

A thorough understanding of the causes and effects of erosion processes requires scientific research. Measurement techniques in scientific research of erosion are aimed at determining causes and effects, as well as the intensity of erosion phenomena. In causeeffect studies, attention is paid to the interdependence of erosion processes and variables. Water erosion processes under natural conditions occurs at various scales of the phenomenon, as well as spatial and time range. Planned and implemented measurements must be appropriate to the scale of the phenomenon. The analysis of water erosion requires the assessment of the intensity of the phenomenon, as well as the volume of soil material loss and identification the places of concentration of erosion processes. In the case of spatial phenomena, such as surface erosion in the form of sheet erosion, intense linear erosion or mass movements in the form of creeping, it is also necessary to determine the spatial extent of water erosion phenomena.

Classical methods of erosion research, such as cartographic or geodetic leveling methods, carry a high risk of error, are imprecise, and require a large interpolation of data. On the other hand, classic sediment fence methods [14-18] require constant installation of measuring devices, which make the object impossible to use as communication route and skidding facility. At the same time, these are measurements that give results only in terms of the volume of soil material loss, and not about the extent and size of erosion phenomena.

Terrestrial laser scanning (TLS) technology has changed the way of analysing the natural phenomena like erosion processes. Geodesy surveying has evolved into 3D models analyses [19-21]. The use of laser technology in the research of erosion phenomena is becoming more common. From a technical point of view, laser scanning is a development and modernization of methods used in geodesy. TLS systems are also referred to as terrestrial LiDAR (Light Detection and Ranging). The determination of the position in the space of the analysed object is determined on the basis of the angle and distance between the source of the wave and the object. Non-contact measurement of distance by a laser beam, combined with precise measurement of angles, allows determining XYZ coordinates of the measured point, and in the case of surface analyses, 
each point from the received points cloud representing the object. Studies using TLS on various types of soil water erosion processes have been conducted in recent years in many countries [22-27].

In the work, the authors set the following aim and scope: the use of TLS as a modern LiDAR technique in field research to evaluate erosion processes occurring in the geomorphological slope environment of the forest skid trail and determine the intensity and spatial extent of erosion phenomena.

\section{Material and methods}

\subsection{Site description}

For this study, a forest area was chosen, where in 2010 logging was realised in accordance with the forest management plan that was in force. For the correct and efficient conducting of the logging, skid trails were demarcated, which timber were transported from the place of cutting to the place of storage located along the access road.

The research object (skid trail of heavy mechanical vehicles logging) is located on the slopes of Ciemniak in the Western Sudetes, Poland (N: 50 51' 33", E: 15 34' 45"; PUWG-92 259338, 338047) within the Szklarska Poręba Forest District (The State Forests National Forest Holding). The skid trail passes almost from the peak of Ciemniak to forest road located across to the slope at the bottom of the hillside. From the entire length of the trail, a section of ca. $77 \mathrm{~m}$ was selected for observation and analysis, which is characterized by an average slope of ca. $10 \%$. The total area of the analysed skid trail is ca. $200 \mathrm{~m}^{2}$. As part of this work, the authors want to present the results of measurements, as well as analysis and evaluation of water erosion processes that occurred at the upper, initial section of the trail. This section is ca. $15.6 \mathrm{~m}$ long, has area ca. $41 \mathrm{~m}^{2}$, and longitudinal slope ca. 35\% (Fig. 1). The paper presents the change of terrain relief of the skid trail, resulting only from erosion phenomena, in the period 2011-2013, with measurements performed annually in November.

In the spring 2010 to the end of 2012, the analysed skid trail hadn't been used. At the beginning of 2013, it was necessary to use heavy forest vehicles on the area and use to the skidding the analysed trail, which was the result of interventional forest works in order to protect the forest. These treatments were not planned in arranging and planning the experiment. However, this phenomenon was also used in the analysis of erosion phenomena with particular attention to the direct impact of skidding and using the skid trail.

For the analysed forest area a digital terrain model (DTM) of $1 \mathrm{~m}$ spatial resolution from the IT system of the Country's Protection Against Extreme Hazards (ISOK) project was available, on the basis of which the area of the entire slope was analysed. Using the flow direction and flow accumulation models, no foreign inflow to the surface of the analysed object was found. The water erosion processes that occurred on the surface of the skid trail were only the result of rainfall, surface flushing (sheet erosion) and concentrated runoff. The analysis also included soil conditions on the surface of the skid trail, making an outcrop and analysing the material in the laboratory. It was found that there is a sandy loam (soil), a material medium susceptible to erosion processes. 


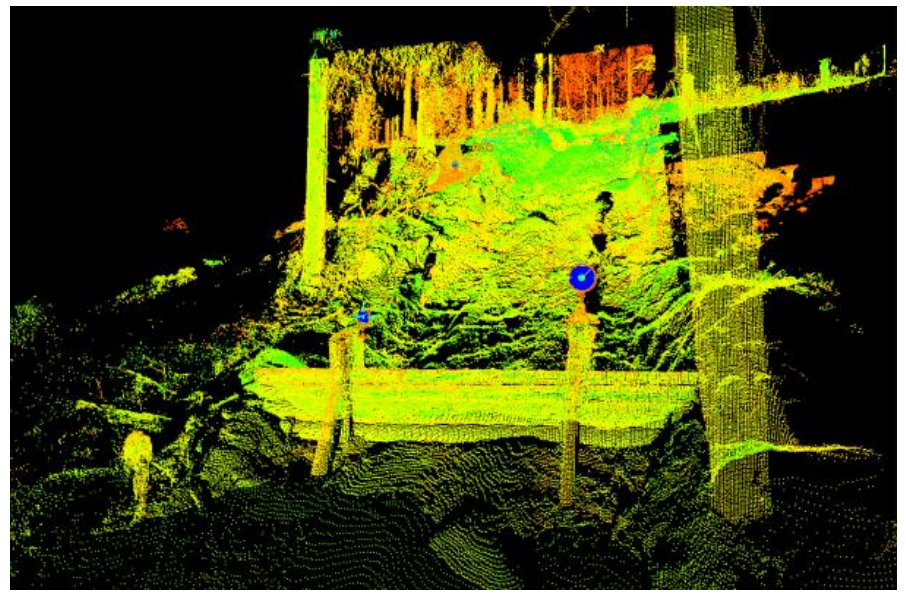

Fig. 1. Analysed skid trail section shown as unclassified points cloud obtained by TLS.

Assuming a rainfall as the causative factors of erosion phenomena, rainfall events in the 2011-2013 period were also analysed for a summer half-year of the hydrological year (April - October period). Due to the presence of snow cover in the winter months, no precipitation was analysed. The average sum of multiannual precipitation in this period for this region is ca. $525 \mathrm{~mm}$. The April - October period in 2012 was characterized by the sum of rainfall ca. $550 \mathrm{~mm}$, and it was the average condition in terms of humidity conditions in relation to the multiannual values. However, in the period April - October in 2013, the sum of precipitation exceeded $700 \mathrm{~mm}$, which means that it was a very wet period. In terms of extreme events, it can be noted that the monthly sum of precipitation in May, June and September 2013 exceeded more than double the multiannual value for those months and these were each month extremely wet.

\subsection{Terrestrial Laser Scanning in soil erosion research}

Terrestrial laser scanning technology was used to analyse the intensity and spatial extent of water erosion processes on the forest skid trail. The applied laser technique of automatic measurement allowed obtaining measurable, fully objective terrain models in a short time. The measurement campaigns were conducted in November 2011, 2012 and 2013. The execution of each measurement campaign did not take more than 5-6 hours. The scan resolution was made of $3 \times 4 \mathrm{~mm}$ at a distance of $10 \mathrm{~m}$. The accuracy of the combination of scans for a single measuring campaign, did not exceed $\pm 3 \mathrm{~mm}$. Accuracy obtained for all measurement campaigns did not exceed $\pm 1.5 \mathrm{~cm}$ (according to program procedure report). The average density of point clouds was about 16,000 point per $\mathrm{m}^{2}$.

In order to remove noise and extract only points representing the ground class, the point cloud from each measurement campaign was subjected to filtration with the ground routine algorithm in the TerraScan environment [28]. Then in the Surfer geostatistic environment as a result of interpolation by the kriging method [21] digital terrain models (DTMs) of the skid trail surface in GRID format with a spatial resolution of $1 \mathrm{~cm}$ were created (Fig. 2). DTM $1 \mathrm{~cm}$ enables accurate analysis of rills occurred as a result of erosion processes, even a few centimetres changes in the terrain relief, as well as the evaluation of the sheet erosion volume.

The analysis of the data involved the creation of differential models. From the control model (model created from the previous measurement campaign), the outcome DTM (models from the later campaign) was subtracted, which resulting in a terrain differential model (Fig. 3). The developed differential DTM allows for observation changes in terrain 
microrelief of the analysed object, as well as the amount and scale of changes. If in the period between measuring campaigns erosion phenomena had occurred, which resulted in changes of the terrain relief, both in the vertical axis (change in the terrain height, change in the thickness of the soil cover) and horizontal axis (e.g. creation or transformation of rills), this differential models method enables quantitative and qualitative assessment of erosion phenomena.

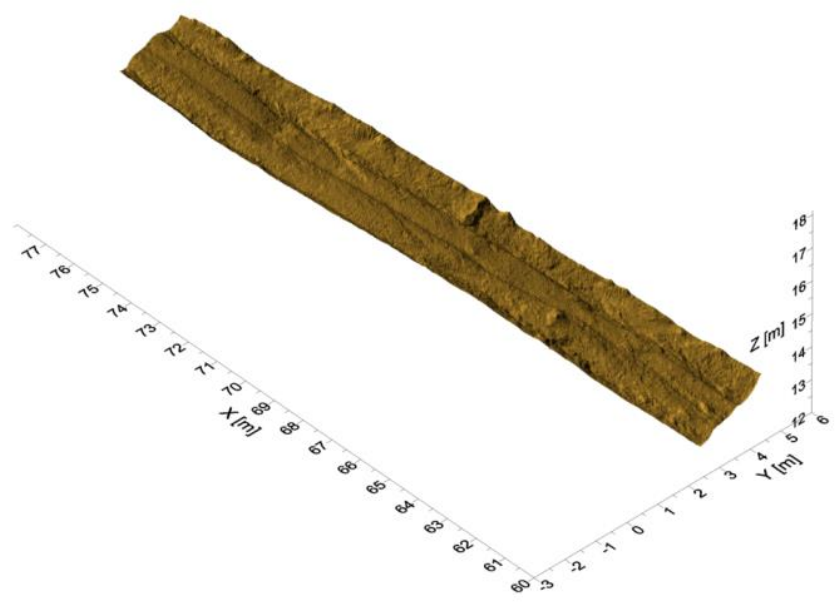

Fig. 2. Detailed DTM $1 \mathrm{~cm}$ of selected skid trail section (a scanner coordinate system).

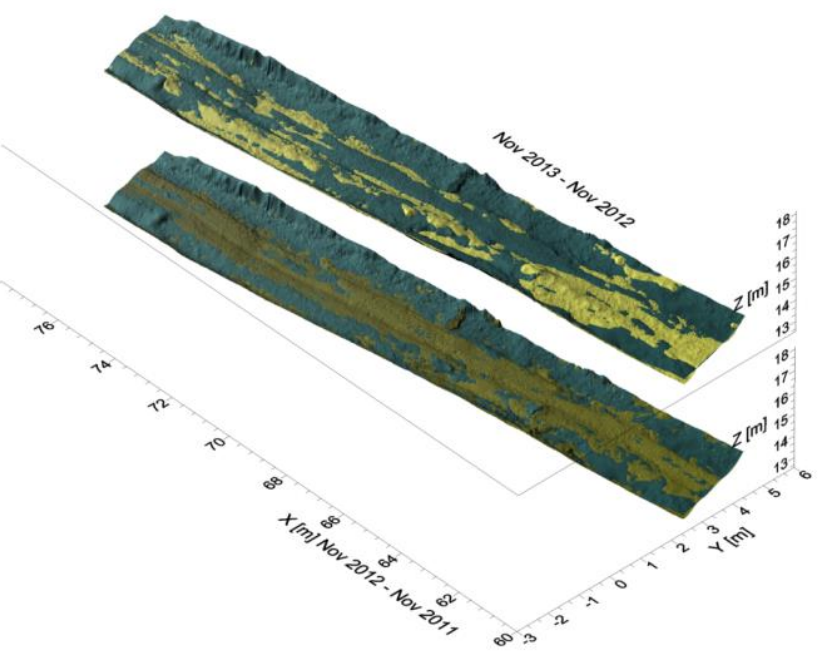

Fig. 3. Differential model method analyses of the primary and control DTMs respectively for the Nov 2012-Nov 2011 and Nov 2013-Nov 2012 period (a scanner coordinate system). 


\section{Results}

The analysis of the intensity and extent of erosion phenomena resulting from surface flushing (sheet erosion) and linearly concentrated runoff on a selected section of the skid trail in the mountainous area, Western Sudetes, Poland, was performed in three measurement campaigns in November 2011, 2012 and 2013.

Two differential analyses were performed based on DTMs and differential DTMs, assuming as a control DTM from November 2011 and an output DTM from November 2012, a control DTM from November 2012 and an output DTM November 2013. The results of each analysis are presented on contour maps (Fig. 4) with a coloured scale representing the change in terrain relief in the vertical axis. The negative values used in the study are the lowering of the terrain elevations, i.e. the soil material loss. On the other hand, positive values are an increase in terrain elevations, which may be the result of stopping, accumulating the transported erosion material from the upper surfaces of the analysed section, or for example, undercutting embankment of the trail and landfalling of soil material. The value of $0 \mathrm{~m}$ corresponds to the state when the landform of the trail in the analysed period has not changed (no effects of erosion phenomena and accumulation of soil material). Table 1 presents the results of the analysis in detail by defining the volume of soil material loss in the terms of individual erosion forms. It was assumed that sheet erosion result in a change of terrain elevation in ordinates (meters above sea level) in the range up to $5 \mathrm{~cm}$. Rill erosion is the processes caused by the linear concentration of runoff, resulting in the creation of numerous small channels with a depth of up to several dozen centimetres. Thanks to the use of spatial analyses, the range of individual erosion forms that were observed and measured during the research period was also determined (Table 1).
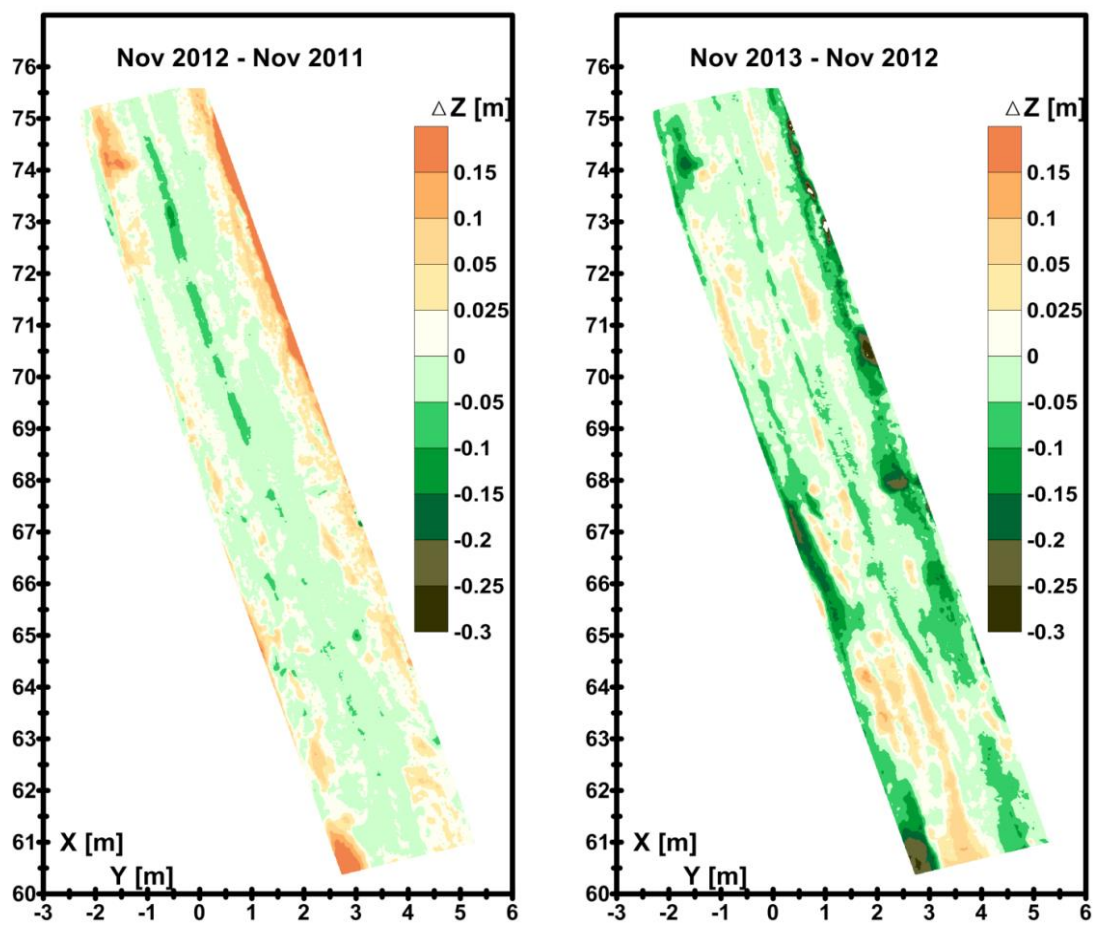

Fig. 4. Contour maps of the differential models of the analysed skid trail section (a scanner coordinate system). 
Table. 1. Results of water erosion measurements in the form of sheet erosion and rill erosion at the analysed skid trail.

\begin{tabular}{|c|c|c|c|}
\hline $\begin{array}{l}\text { depth } \\
\text { h [m] }\end{array}$ & $\begin{array}{c}\text { volume } \\
\text { V }\left[\mathbf{d m}^{3}\right]\end{array}$ & $\begin{array}{l}\text { depth } \\
\text { h [m] }\end{array}$ & $\begin{array}{c}\underset{A}{\operatorname{area}}\left[\mathbf{m}^{2}\right]\end{array}$ \\
\hline \multicolumn{4}{|c|}{ Nov 2012 - Nov 2011} \\
\hline$(0.00 ;-0.05>$ & 372.0 & $(-0.20 ;-0.25>$ & 0.0016 \\
\hline$(-0.05 ;-0.10>$ & 20.2 & $(-0.15 ;-0.25>$ & 0.0035 \\
\hline$(-0.10 ;-0.15>$ & 0.7 & $(-0.10 ;-0.25>$ & 0.0519 \\
\hline$(-0.15 ;-0.20>$ & 0.1 & $(-0.05 ;-0.25>$ & 1.1975 \\
\hline$(-0.20 ;-0.25>$ & 0.1 & $(0.00 ;-0.25>$ & 21.3664 \\
\hline$\underline{\underline{\Sigma}}$ & $\underline{393.1}$ & & \\
\hline \multicolumn{4}{|c|}{ Nov 2013 - Nov 2012} \\
\hline$(0.00 ;-0.05>$ & 960.4 & $(-0.35 ;-0.40>$ & 0.0030 \\
\hline$(-0.05 ;-0.10>$ & 351.5 & $(-0.30 ;-0.40>$ & 0.0249 \\
\hline$(-0.10 ;-0.15>$ & 119.1 & $(-0.25 ;-0.40>$ & 0.1342 \\
\hline$(-0.15 ;-0.20>$ & 48.9 & $(-0.20 ;-0.40>$ & 0.6049 \\
\hline$(-0.20 ;-0.25>$ & 17.5 & $(-0.15 ;-0.40>$ & 1.4342 \\
\hline$(-0.25 ;-0.30>$ & 3.4 & $(-0.10 ;-0.40>$ & 3.7319 \\
\hline$(-0.30 ;-0.35>$ & 1.0 & $(-0.05 ;-0.40>$ & 11.5751 \\
\hline$(-0.35 ;-0.40>$ & 0.1 & $(0.00 ;-0.40>$ & $\underline{28.7099}$ \\
\hline$\underline{\Sigma}$ & 1501.9 & & \\
\hline
\end{tabular}

The obtained results allow stating that the total amount of soil material loss in the years 2011-2013 from the area of the analysed section of the skid trail was about $1.9 \mathrm{~m}^{3}$. In total, erosion processes in every forms occurred at ca. $52 \%$ and ca. $70 \%$ of the analysed section area, respectively in the period 2011-2012 and 2012-2013. The erosion processes occurred mainly in the form of sheet erosion, both in terms of spatial range and the amount of soil material loss, which was estimated to be ca. $95 \%$ and ca. $64 \%$ of the total amount, respectively. At the same time, the sheet erosion (surface flushing) was occurred ca. 94\% and ca. $60 \%$ of the total area on which erosion processes occurred (ca. $49 \%$ and ca. $42 \%$ of the total area of the analysed section of the skid trail, respectively). The erosion index was also defined, which was specified as the quotient of the volume of the soil material loss and the actual area on which the erosion phenomena occurred, in the appropriate period. The index has values of $18.4 \mathrm{dm}^{3} \cdot \mathrm{m}^{-2}$ and $52.3 \mathrm{dm}^{3} \cdot \mathrm{m}^{-2}$ in the period $2011-2012$ and 2012-2013 respectively.

\section{Conclusions}

The authors undertook an attempt to assess the water erosion processes of soils occurring within the forest skid trail located on the area of Szklarska Poręba Forest District (The State Forests National Forest Holding), in the Western Sudetes, Poland. The research was carried out in 2011-2013. In the study of water erosion processes, a modern technique of remote sensing, the terrestrial laser scanning technology, was innovatively used. 
The obtained results prove the rightness of taking up the topic in the terms of the occurrence of erosion phenomena in mountainous forest areas, which are formed as a result of traced and using of skid trails. The presented analysis of the problem of water erosion processes, allows making following conclusions:

- used laser scanner, adopted scanning resolution and spatial resolution of created DTMs $(1 \mathrm{~cm})$, as well as the applied differential models method allowed recognition of created erosion forms, determining the intensity of water erosion processes of soil on the surface of the forest skid trail, as well as the analyst of erosion processes spatial range and determination of soil material losses caused by water erosion,

- in the terms of forms of water erosion phenomena and their spatial range, as well as the amount of soil material loss, the erosion processes of the top layer of the soil in the form of sheet erosion and the rill erosion to the depth of 5-10 cm prevail,

- sheet erosion occurred in different periods at over $50-70 \%$ of the analysed section of the skid trail,

- soil material loss as a result of sheet erosion was over $1.3 \mathrm{~m}^{3}$ from the actual area of phenomena ca. 17.1-20.1 $\mathrm{m}^{2}$ respectively in periods 2011-2012 and 2012-2013,

- as a result of the linear concentration of runoff, rills were created to a depth of ca. $40 \mathrm{~cm}$,

- direct use of skid trials in forestry works by heavy vehicles strongly affects on the intensity of erosion phenomena due to the loosening of the topsoil, causing increase the range and intensity of erosion processes in period 2012-2013,

- some limitations in the use of TLS in the study of erosion phenomena in highly various terrain can be highlight: the need to have a power generator, the need to connect measurements to an existing geodetic control network, difficulties resulting from current meteorological conditions.

\section{References}

1. M. Licznar, Zesz. Post. Nauk Roln. 418, 91-100 (1995)

2. E. Nowocień, Studia i Raporty IUNG-PIB 10, 9-38 (2008)

3. A. Józefaciuk, E. Nowocień, R. Wawer, Erozja gleb w Polsce: skutki środowiskowe i gospodarcze, działania zaradcze (IUNG-PIB, 2014)

4. C.E. Ramos Scharrón, Catena 82, 146-158 (2010)

5. M. Costea, Proceedings of EED '13, Proceedings of STACH '13, (2013)

6. E. Pierzgalski, M. Janek, K. Kucharska, J. Tyszka, M. Wrobel, Badania hydrologiczne w leśnych zlewniach sudeckich (IBL, Sękocin, 2007)

7. M. Chang, Forest hydrology: An introduction to water and forests (CRC Press LLC, USA, 2003)

8. Y. Luo, X. Zhou, Soil Respiration and the Environment (Elsevier Inc., 2006)

9. M. Akbarimehr, R. Naghdi, Catena 88, 68-72 (2012)

10. W. Kusiak, R. Jaszczak, Propedeutyka leśnictwa (Wyd. Uniwersytety Przyrodniczego w Poznaniu, Poznań, 2009)

11. J. Dzikowski, A. Szarłowicz, S. Burzyński, M. Rajsman, J. Satoła, Z. Wiązowski, Drogi leśne. Poradnik techniczny (Warszawa-Bedoń, 2006)

12. J.D. Hewlett, Principles of Forest Hydrology (Univ. Ga. Press, 1982)

13. J. Croke, P.B. Hairsine, P. Fogarty, Forest Ecol. Manag. 143, 3-12 (2001)

14. J.D. Benavides-Solorio, L.H. MacDonald, Int.J. Wildland Fire 14(4), 457-474 (2005)

15. A. Jordán, L. Martínez-Zavala, Forest Ecol. Manag. 255, 913-919 (2008)

16. I.J. Larsen, L.H. MacDonald, E. Brown, D. Rough, M.J. Welsh, Soil Sci. Soc. Am. J. 73(4), 1393-1407 (2009)

17. L.H. Macdonald, R.W. Sampson, D.M. Anderson, Earth Surf. Proc. Land. 26, 251-272 (2001) 
18. J.D. Ruiz Sinoga, A. Romero Diaz, E. Ferre Bueno, J.F. Martínez Murillo, Catena 80, 131-139 (2010)

19. M. Barbarella, M. Fiani, A. Lugli, Geomatics, Nat. Haz. and Risk 6(5-7), 398-418 (2015)

20. U. Coppa, A. Guarnieri, F. Pirotti, P. Tarolli, A. Vettore, Int. Arch. Photogramm. 40(5W3), 59-62 (2013)

21. G. Vosselman, H.G. Maas, Airborne and Terrestrial Laser Scanning (Whittles Publishing, Dunbeath, Scotland, UK, 2010)

22. J.A. Ballesteros-Cánovas, C. Corona, M. Stoffel, A. Lucia-Vela, J.M. Bodoque, Plant Soil 394(1-2), 127-137 (2015)

23. A. Eltner, C. Mulsow, H.G. Maas, Int. Arch. Photogramm. XL-1/W2, UAV-g2013 (2013)

24. P. Falkowski, Reports on Geodesy 1(82), 61-67 (2007)

25. S.J. Gordon, D.D. Lichti, M.P. Stewart, J. Franke, Proceedings ISPRS Conference V, 1014-1019 (2004)

26. T. Kersten, K. Mechelke, M. Lindstaedt, H. Sternberg, FIG Working Week Stockholm (2008)

27. L. Stenberg, T. Tuukkanen, L. Finér, H. Marttila, S. Piirainen, B. Kløve, H. Koivusalo, Earth Surf. Proc. Land. 41, 1299-1311 (2016)

28. A. Soininen, TerraScan User's Guide (Terrasolid, 2012) 